to the latter question determines considerably the extent to which industries now served by the grantaided research associations can be fairly expected to bear the full financial responsibility for the research associations.

Again, even if the Department's responsibilities for research of direct application to industry are determined largely by the extent to which further research is likely to be stimulated in industry, the extent to which the Department's own stations should engage in such research will not easily be decided without considering the further problem of how to allocate available resources effectively in order to meet the demands which team-work and highly expensive equipment now make. The Couneil, in its first annual report, indicated that these questions were already being considered. Its second report will certainly be awaited with considerablo interest and some anxiety; but in the meantime these surveys have done something to clarify the picture, and to indicate the points at which further information on the national effort is needed-and some at which action is urgently required-if only to check existing waste and to increase the effectiveness with which present limited resources in trained manpower or expensive equipment are used. Even while new policies are being devised, much could be done to make far more effective use of present expenditure and resources, given sufficient imagination, co. operation and drive.

\section{THE FATHER OF CHEMISTRY} Robert Boyle and Seventeenth-Century Chemistry By Prof. Marie Boas. Pp. viii +240 . (Cambridge: At the University Press, 1958.) 30s. net.

R. MARIE BOAS, assistant professor of the history of science in the University of California, gives an account of the achievements of seventeenthcentury chemistry with Robert Boyle as the central figure. The foundation of his development as a scientist is doubtless his early interest in collecting medical recipes and preparing medicaments. $\mathrm{He}$ soon became an ardent experimentalist, using the "Book of Nature" as his teacher. He came to regard chemistry as "highly conducive to the true knowledge of Nature", and to be not only a necessary part but also a respectable and useful part of natural philosophy, able to "contribute to its advance as a whole".

The chemical and physical theories of matter current in Boyle's time did not satisfy him, and he developed a mechanical, corpuscular theory, based on experiment, by which he strove to banish all occult notions from natural philosophy. In "The Sceptical Chymist" he demolished the established theory of elements in its various forms, and ended by being doubtful of the existence of any elements. Dr. Boas points ous the great difference between the concept of elements then and now, and stresses its importance for a proper understanding of seventeenth-century chemical theory and Boyle's objections to it. His rejection of the old view of a chemical element paved the way for the concept of simple substances, which le.l ultimately to the new definition of element. His firm belief in corpuscular philosophy apparently provides the explanation of his belief in transmuta. tion, since he considered the change from one metal to another to involve merely a change in corpuscular structure.

The increase in the number of substances resulting. from experimental work inevitably raised the problem of chemical composition. Throughout this period the attempt was made to improve chemical nomenclature, basing it on chemical entities instead of imaginary elements or principles. Chemical reactions presented great difficulty, and only gradually came to be regarded as a combination or an interchange of chemical entities. The method of analysis by fire frequently gave very good results, but difficulties in interpretation arose from the confusion caused by variations in experimental technique, and inaccurate nomenclature. Chemical identification tests werc greatly extended in scope by Boyle, who evolved precipitation tests, colour reactions, flame tests, and indicators for alkalis.

At an early date Boyle interested himself in chemical classification. His suecessful classification of acids, alkalis, and neutral substances killed the acid-alkali theory of matter. He recognized that acids had two parts : one that caused all acids to give a colour change with an indicator; the other that made one acid different from another. He was not so successful in his attempts at nomenclature for salts. Boyle's experiments on air are discussed. He could not "believe that the elastic particles of the air are really chemical entities", and he regarded fire, rather than air, as the chief agent responsible for calcination, and the increase in weight of metals.

Boyle's scientific method and experimental technique are discussed in the final chapter. His writings are prolix and frequently tedious; his method of preserving the records of his work prior to publication was haphazard, if not careless; but in contrast to this his experimental work was carefully conceived, detailed, and properly noted at the time. He was a shrewd observer, and no stranger to the use of quanti. tative methods, even if he was not as accurate with them as he could have been, and at times failed to interpret the results correctly.

The bibliography adequately covers the subject. The index, too, is adequate, but curiously omits all mention of any of the works of Boyle discussed in the text. For references to Boyle's life the octavo edition of 1744 has been used, and for his works the folio edition of the same year. From the point of view of accessibility the quarto edition of 1772 would per. haps have been a better choice for both purposes. Some of the references to the archives of the Royal Society are confusing because the system of nomenclature used by that body has not been adopted. The following corrections, among others, may be noted: p. 9, Boyle returned to England in mid-1644, not in 1645 ; p. 11, Add. MSS 4316 should be 4314 ; p. 24, Gerard Boate died in 1650, not 1653 ; and "Ireland's Naturall History" was published under" his name as sole author; p. 30, Boyle was in Ireland by the last week of June $1652 ;$ p. 211 , the reference should read "Royal Society. Correspondence. Early Letters. Guardbook B.1. 100", and the date of the letter is "9 Dec" not " 2 Dec". These, however, are minor errors, and in no way detract from the brilliance of this important book, in which Dr. Boas, with a skilful marshalling of widely distributed facts from Boyle's works and papers, conducts the reader in virtuoso manner through the labyrinth of seventeenth-century chemical thought and practice.

\section{R. E. W. Madorson}

